\title{
Silver-Derived Antimicrobial Coatings for the Prevention of Microbial Biofilms in Metal Pipes
}

\author{
M. Vela-Cano $\cdot$ C. Garcia-Fontana $\cdot$ F. Osorio $\cdot$ \\ A. González-Martinez • J. González-López
}

Received: 21 February 2021 / Accepted: 8 July 2021

(C) The Author(s) 2021

\begin{abstract}
Biodeterioration is one of the most important processes in metal pipeline corrosion, and it can be due to physical, chemical, and biological factors. Coatings rich in silver have been used to inhibit this undesirable phenomenon. In this study, the antimicrobial properties of several silver-containing products used as a coating in pipelines were determined on a pilot scale in order to evaluate the ability of silver to inhibit biofilm formation. The results showed that the coating with silver zeolite at a concentration of $2000 \mathrm{mg} \mathrm{L}^{-1}$ inhibited the formation of a microbial biofilm and prevented the biodeterioration process. Therefore, from our study, it can be concluded
\end{abstract}

M. Vela-Cano and C. Garcia-Fontana contributed equally to this work.

\footnotetext{
M. Vela-Cano $(\bowtie) \cdot$ A. González-Martinez ·

J. González-López

Institute of Water Research, Edificio Fray Luis de León, C/

Ramón Y Cajal, 4, 18071 Granada, Spain

e-mail: mvc@ugr.es

C. Garcia-Fontana

Instituto de Investigación Biosanitaria de Granada (Ibs. GRANADA), Hospital Universitario San Cecilio de Granada, 18016 Granada, Spain

C. Garcia-Fontana

CIBERFES, Instituto de Salud Carlos III, Madrid, Spain

F. Osorio

Department of Civil Engineering, University of Granada, Campus de Fuentenueva, s/n, 18071 Granada, Spain
}

that silver zeolite shows greater protection capacity than other silver preparations and presents advantages in relation to other silver coatings that are currently available

Keywords Biofilm formation - Silver coat · Antimicrobial treatment $\cdot$ Pilot-scale plant

\section{Introduction}

Corrosion is one of the most important processes in pipeline deterioration (Cheng, 2013). It can be due to physical, chemical, and biological factors (Maruthamuthu et al., 2011; Santillan et al., 2015). Several kinds of microorganisms have been described as responsible for initiating or accelerating the corrosion process (Videla \& Herrera, 2009). In this context, the formation of microbial biofilms affects different metal pipes, such as those in water distribution system. Biofilms are composed of an association of colonies of microorganisms and organic and/or inorganic material that causes corrosion of the pipes (McNeill \& Edwards, 2001). Microbial communities that are commonly associated with pipeline corrosion include sulphate-reducing bacteria (SRB), acetogenic bacteria, and methanogens (Dinh et al., 2004; Liang et al., 2014; Okoro et al., 2016). The presence of biofilms in pipelines also affects the colour of the water (Husband et al., 2008), as well as its smell and taste (Szewzyk et al., 2000). In addition, the formation of biofilms can lead to serious hygiene problems and economic losses due to the 
deterioration of equipment (Bremer et al., 2006), whose reparation costs are around millions of dollars per year (Valix et al., 2012; Sánchez-Silva \& Rosowsky, 2008).

Several strategies have been tested to prevent biofilm formation; however, nowadays there are no known techniques capable of preventing or successfully controlling the formation of biofilms without causing other undesired effects. Until now, the most extended practice to prevent the formation of these bacterial accumulations has been to regularly clean and disinfect the pipelines (Midelet \& Carpentier, 2004; Simoes et al., 2005). Another possible solution is to use pipe coatings with antimicrobial agents. To date, numerous studies have been carried out to verify the antimicrobial capacity and/or resistance to colonization of various materials and compounds. Some of these studies are listed in Table 1.

However, many of them are not effective (Momba and Kfir, 2000) because several of the biofilm-forming bacterial species show resistance to disinfectant treatments (Ridgway \& Olson, 1982). For this reason, it is necessary to deeply investigate other possible options to reduce biofilm formation in pipeline networks.

In studies carried out in recent years, it has been proven that silver $(\mathrm{Ag})$ is able to act strongly against a wide range of bacterial and fungal species (Cao \& Liu, 2010). In fact, surfaces treated with silver have a notable inhibitory capacity in the formation of biofilms (Hashimoto, 2001; Klueh et al., 2000). It has been observed that coatings rich in silver result in complete inhibition of microbial adherence. However, the antimicrobial properties of silver are not wellknown. Thus, the aim of this study was to investigate the antimicrobial properties of several products used as coatings in pipelines that contain different amounts of silver and to evaluate the inhibition of the biofilm formation process in metal pipes. This study was carried out on both a lab scale using pure cultures of microorganisms previously described as excellent biofilm formers and under pilot plant conditions that reproduced real operating conditions.

Table 1 Treatment used for biofilm detachment

\begin{tabular}{|c|c|c|}
\hline Treatment & Biofilm & Reference \\
\hline Ozone, chlorinated commercial disinfectant & $\begin{array}{l}\text { Pseudomonas fluorescens and Alcaligenes } \\
\text { faecalis }\end{array}$ & Greene et al. (1993) \\
\hline $\begin{array}{l}\text { Benzalkonium chloride, hexadecyltrimethyl- } \\
\text { ammonium bromide, sodium hypochlorite, } \\
\text { peracetic acid, hydrogen peroxide }\end{array}$ & Escherichia coli & Ntsama-Essomba et al. (1997) \\
\hline Chlorine, peracetic acid, peroctanoic acid & $\begin{array}{l}\text { Mixed biofilm of Listeria monocytogenes and } \\
\text { Pseudomonas sp. }\end{array}$ & Fatemi and Frank (1999) \\
\hline Disinfectant containing chlorine dioxide & $\begin{array}{l}\text { Biofilms of Bacillus cereus and Pseudomonas } \\
\text { fluorescens }\end{array}$ & Lindsay et al. (2002) \\
\hline Chlorine & Escherichia coli & Lomander et al. (2004) \\
\hline $\begin{array}{l}\text { Chlorinated alkaline solution, detergent with low } \\
\text { phosphate concentrations, double peracid solu- } \\
\text { tion, alkaline solution, hypochlorite }\end{array}$ & Listeria monocytogenes & Somers and Wong (2004) \\
\hline $\begin{array}{l}\text { Sodium hydroxide, alkaline cleaner for profes- } \\
\text { sional use }\end{array}$ & Pseudomonas putida & Antoniou and Frank (2005) \\
\hline $\begin{array}{l}\text { Glutaraldehyde, ortho-phthalaldehyde, hexa- } \\
\text { decyltrimethylammonium bromide, sodium } \\
\text { dodecyl sulphate }\end{array}$ & Pseudomonas fluorescens & Simoes et al. (2005) \\
\hline Sodium hydroxide, nitric acid & Mixed species & Bremer et al. (2006) \\
\hline Peroxides, quaternary ammonium compounds & Listeria monocytogenes & Pan et al. (2006) \\
\hline $\begin{array}{l}\text { Hydrogen peroxide, sodium dichloroisocyanu- } \\
\text { rate, peracetic acid }\end{array}$ & Staphylococcus aureus & Marques et al. (2007) \\
\hline $\begin{array}{l}\text { Polydimethylsiloxane (PDMS), microcrystalline } \\
\text { cellulose (MCC), silver nanoparticles }\end{array}$ & Escherichia coli and $S$. aureus & Jankauskaite et al. (2014) \\
\hline $\begin{array}{l}\text { Hydroxyapatite doped with zinc, hydroxyapatite } \\
\text { doped with silver }\end{array}$ & Candida albicans & Groza et al. (2016) \\
\hline
\end{tabular}




\section{Materials and Methods}

\subsection{Antibacterial Products}

Ten rectangular sections of metal pipes previously washed with ethanol, bleach, and distilled water were coated with antimicrobial agents containing different concentrations of silver. The metal sections coated with the antimicrobial paints were supplied by the Cetaqua Foundation. An additional section with any type of coating was used as a control. A total of 11 sections were tested (Table 2).

\subsection{Bacteria}

Pseudomonas aeruginosa PAO1 was selected as a model microorganism to assay its capacity to form a biofilm on the different surfaces used in this study. This bacterium has been reported as microorganism being able to form biofilms on iron and other metal surfaces (Kang et al. 2006; Steele et al. 1994; Wallace et al., 1994).

\subsection{Batch Experiments}

Batch studies were conducted by immersing each section of the metal pipes into 1-L beakers containing $600 \mathrm{~mL}$ of trypticase soy broth (TSB) (Fig. 1). All beakers were inoculated with a bacterial suspension of $P$. aeruginosa to obtain an initial optical density of 0.04. To avoid anaerobic conditions, the beakers were incubated in an orbital shaker (HWY-211) at $30{ }^{\circ} \mathrm{C}$ and $60 \mathrm{rpm}$ for 4 days.

\subsection{Biofilm Quantification}

After 4 days of incubation, all sections of the metal pipes were softly washed with sterile distilled water to separate non-adhered biomass from the plates. Then, adhered biofilms were separated by sonication of each piece for $10 \mathrm{~min}$ in $200 \mathrm{~mL}$ of sterile distilled water. Each sample was centrifuged at $6000 \mathrm{rpm}$ for $40 \mathrm{~min}$, and the obtained biomass was collected and weighed. To confirm the results, this process was done twice. All determinations were carried out in triplicate. After that, the two most effective coatings were chosen for intense research in a pilot-scale plant.

\subsection{Description of the Pilot-Scale Experimental Plant}

A pilot plant on a lab scale was used in this research. The pilot plant was built with stainless steel. It consisted of 9 hermetically closed compartments with unit dimensions of $300 \times 90 \times 90 \mathrm{~mm}$ (length $\times$ width $\times$ height). The flow within each compartment was horizontal. In the centre of each compartment, one section of metal pipe was inserted perpendicular to the water flow (Fig. 2a and b). The water used in our experiment was obtained from a well located in the city of Manilva (Malaga) used to supply drinking water. The experiment was performed in triplicate.
Table 2 Coatings applied to metal sections containing different silver preparations

\begin{tabular}{lll}
\hline Treatment & Painting with antibacterial agent & $\begin{array}{l}\text { Silver in paint } \\
\text { used for coat- } \\
\text { ing } \\
(\mathrm{mg} / \mathrm{mL})\end{array}$ \\
\hline 1 & & 380 \\
2 & Silver antibacterial gel & 2850 \\
3 & Silver antibacterial gel & 375 \\
4 & $\mathrm{AgCl}+\mathrm{TiO}_{2}$ & 3750 \\
5 & $\mathrm{AgCl}+\mathrm{TiO}_{2}$ & 500 \\
6 & $\mathrm{ZeAg}($ silver zeolite) & 2000 \\
7 & $\mathrm{ZeAg}$ (silver zeolite) & 1300 \\
8 & $\mathrm{Colloidal}$ silver & 100 \\
9 & $\mathrm{CPS}$ (silver citrate) & 400 \\
10 & FZrAg (zirconium and silver phosphate) & 4000 \\
Control & FZrAg (zirconium and silver phosphate) & 0 \\
\hline
\end{tabular}


Fig. 1 Submerged plate in the bacterial suspension (Pseudomonas aeruginosa PAO1) at the beginning of the incubation period

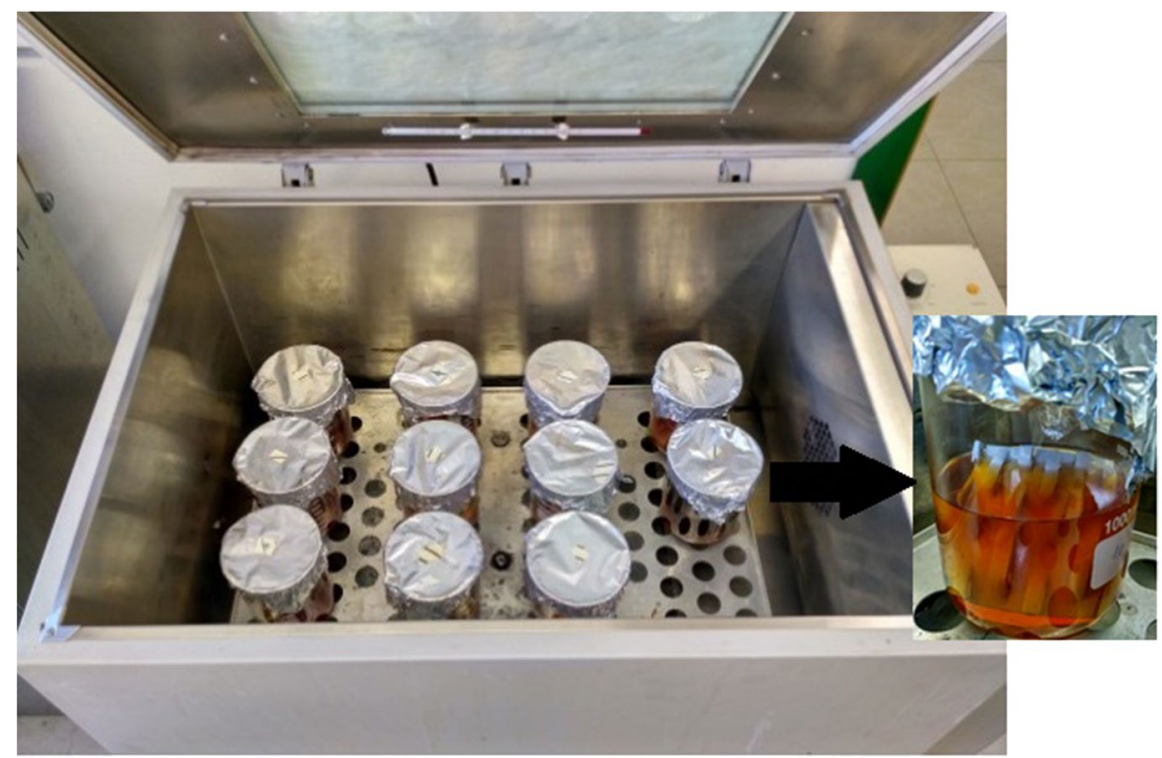

Fig. 2 a Schematic diagram of the pilot plant. b Plant view of the pilot plant.

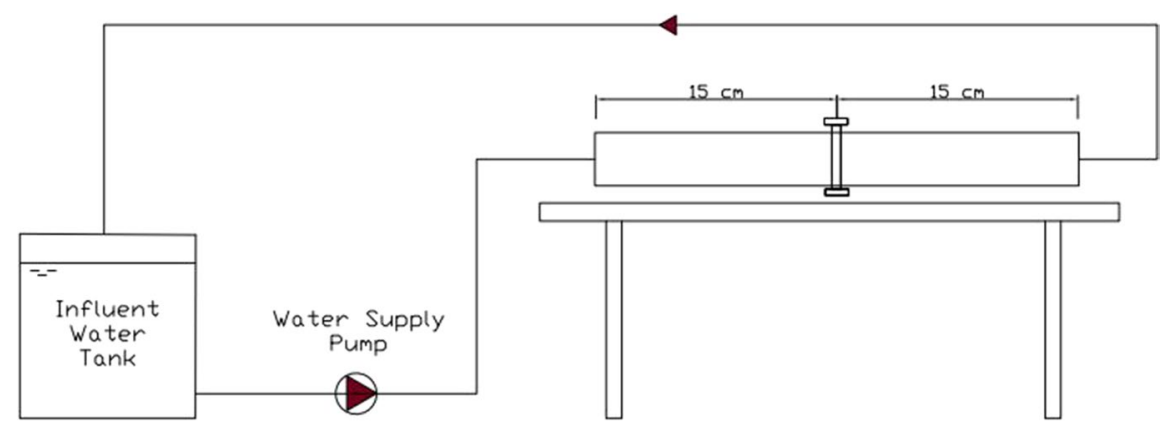

a

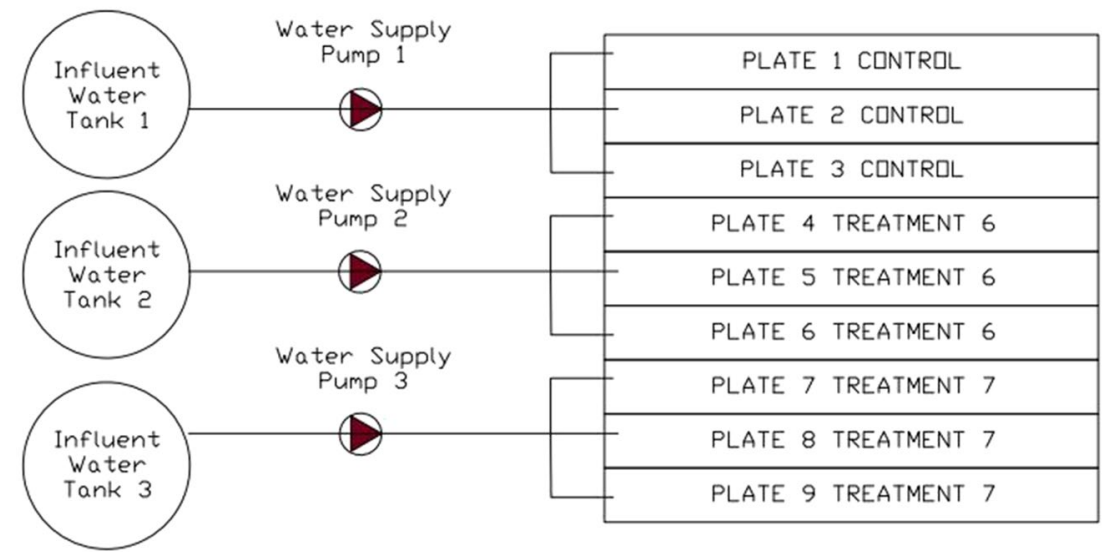

b
The vertical disposition of the metal pipe sections in a plane perpendicular to the water flow realistically simulated the water flow through the abstraction grids of a real well. In the nine compartments, which operated independently in parallel, the following three types of materials were installed: 
three control metal sections without antimicrobial paint, three metal sections treated with silver zeolite $(\mathrm{ZeAg})$ (treatment 6), and three metal sections treated with colloidal silver (treatment 7).

The physicochemical properties of groundwater were checked weekly throughout the experiment. One of the three metal sections of each treatment was collected after 3, 6, and 9 weeks, respectively, and the formation of biofilms was analyzed following the protocol described above. The groundwater used to feed the pilot plant was obtained from a supply well in the city of Manilva (Malaga). The physicochemical and microbiological composition of water is detailed in Table 3.

Thus, the system consisted of three water supply tanks made of polyethylene, with a unit capacity of 15 L. Inside each tank, a submerged pump was incorporated, which provided a constant flow of $50 \mathrm{~L} \mathrm{~min}^{-1}$. With this flow, identical for the nine compartments, and taking into account the sectional area of the compartments $\left(90 \times 90 \mathrm{~mm}^{2}\right)$, the water flow velocity was in them of $10 \mathrm{~cm} \mathrm{~s}^{-1}$. This velocity is on the order of the flow velocity for the abstraction water in the well gratings of real installations.

The physicochemical properties of groundwater were checked weekly throughout the experiment (9 weeks). The metal pipe sections were collected after 3, 6, and 9 weeks, and biofilm formation was analyzed following the protocol described above.

\subsection{Statistical Study}

One-way analysis of variance (ANOVA) was performed using the software package Statgraphics 3.0

Table 3 Physicochemical and microbiological characteristics of the groundwater used in the pilot-plant experiments

\begin{tabular}{llll}
\hline $\begin{array}{l}\text { Physicochemical } \\
\text { characteristics }\end{array}$ & $\begin{array}{l}\text { Microbial counts } \\
\left(\text { CFU } 100 \mathrm{~mL}^{-1}\right)\end{array}$ & \\
EC $^{*}$ & $1525 \mathrm{~s} / \mathrm{m}$ & Enterococcus & 0 \\
$\mathrm{pH}$ & 7.8 & E. coli & 0 \\
Cations $\left(\mathrm{mg} \mathrm{L}^{-1}\right)$ & Anions $\left(\mathrm{mg} \mathrm{L}^{-1}\right)$ & & \\
Calcium & 137.1 & Bicarbonate & 329 \\
Magnesium & 41.4 & Chlorides & 305 \\
Potassium & 2.8 & Nitrates & 1.3 \\
Sodium & 160.2 & Sulphates & 157 \\
\hline
\end{tabular}

*EC, electrical conductivity
Plus version (STSC Inc., Rockville, MD, USA) in order to identify the antimicrobial effects of the different coats used. A significance level of 95\% $(p<0.05)$ was selected.

\section{Results and Discussion}

Several techniques have been designed to prevent biofilm formation, and most of them consist of periodically cleaning and disinfecting the equipment with chemical compounds (Midelet \& Carpentier, 2004), the installation of biofilm detectors to monitor surface colonization (Pereira et al., 2008), or the identification of materials that avoid or hinder the accumulation of microbiological biomass (Rogers et al., 1994). However, none of these methods have completely inhibited the adhesion of microorganisms to materials. For this reason, in recent years, attempts have been made to avoid biofilm formation by incorporating antimicrobial products onto the surfaces of materials (Park et al., 2004; Weng et al., 1999). As has been shown in other studies (Hashimoto, 2001; Klueh et al., 2000), compounds that contain silver in their formulation appear to be highly effective since almost complete inhibition of bacterial adherence is observed. Thus, the results offered in this study were focused on evaluation of the antimicrobial activity of different treatments to prevent biofilm development.

Table 4 shows the amount of biomass adhered to each section of pipe material. It was evident that the size of the biofilms was larger in the control section without treatment than in the section treated with a silver coating. The percent reduction increased from $34.01 \%$ for treatment 1 to $96.18 \%$ for treatment 6 and $87.9 \%$ for treatment 7 .

In our study, it was concluded that treatments 6 and 7 (silver zeolite) were the most effective at preventing the formation of biofilms. In recent years, silver compounds have been applied in various fields because of their low toxicity for human health, low volatility, and high thermal stability (Wai-Yin Sun et al., 2005). In this respect, it has been observed that silver delays the growth of microbial biofilms (Silver, 2003). Thus, the data obtained in this work show that silver zeolite and colloidal silver have a remarkable ability to reduce biofilm formation. 
Table 4 Biofilm formation in metallic sections of pipes covered with paints containing different concentrations of silver

\begin{tabular}{llll}
\hline Treatment & Weight $(\mathrm{g})$ & Reduction $(\%)$ & $\begin{array}{l}\text { Qualitative } \\
\text { apprecia- } \\
\text { tion }\end{array}$ \\
\hline 1 & $0.475 \pm 0.25$ & 34.01 & Poor \\
2 & $0.425 \pm 0.09$ & 38.72 & Poor \\
3 & $0.425 \pm 0.11$ & 38.96 & Poor \\
4 & $0.225 \pm 0.04$ & 67.32 & Poor \\
5 & $0.115 \pm 0.09$ & 81.39 & Good \\
6 & $0.025 \pm 0.01$ & 96.18 & Excellent \\
7 & $0.080 \pm 0.01$ & 87.92 & Excellent \\
8 & $0.400 \pm 0.14$ & 43.27 & Good \\
9 & $0.255 \pm 0.09$ & 63.87 & Good \\
10 & $0.400 \pm 0.05$ & 40.94 & Good \\
Control & $0.695 \pm 0.16$ & - & \\
\hline
\end{tabular}

Data are the mean of three replicates \pm the standard deviation
Moreover, our data suggest that those treatments produce better results than other metallic coatings in relation to their inhibitory effect on the formation of biofilms. Matsumura et al. (2003) studied the antimicrobial activity of silver zeolite and silver nitrate against Escherichia coli, and they proved that silver zeolite was more effective at inhibiting biofilm formation. Kim et al. (2011) reported that the growth of Staphylococcus aureus and Escherichia coli were inhibited on surfaces treated with silver nanoparticles, even when external conditions such as $\mathrm{pH}$ or temperature were modified.

In addition to the aforementioned results, it was found that the metal pipe sections covered with zoolite paint suffered less biodeterioration than those subjected to other treatments (Fig. 3). Thus, when the sections that underwent treatments 6 and 7 were observed, it was evident that they remained practically unchanged throughout the study period, and this was not detected in the other sections and especially in the control without any treatment.
Fig. 3 Images of metal pipes covered with paints containing different silver preparations (treatments 1 to 10) after 4 days of incubation in liquid medium (trypticase soy broth) inoculated with $P$. aeruginosa

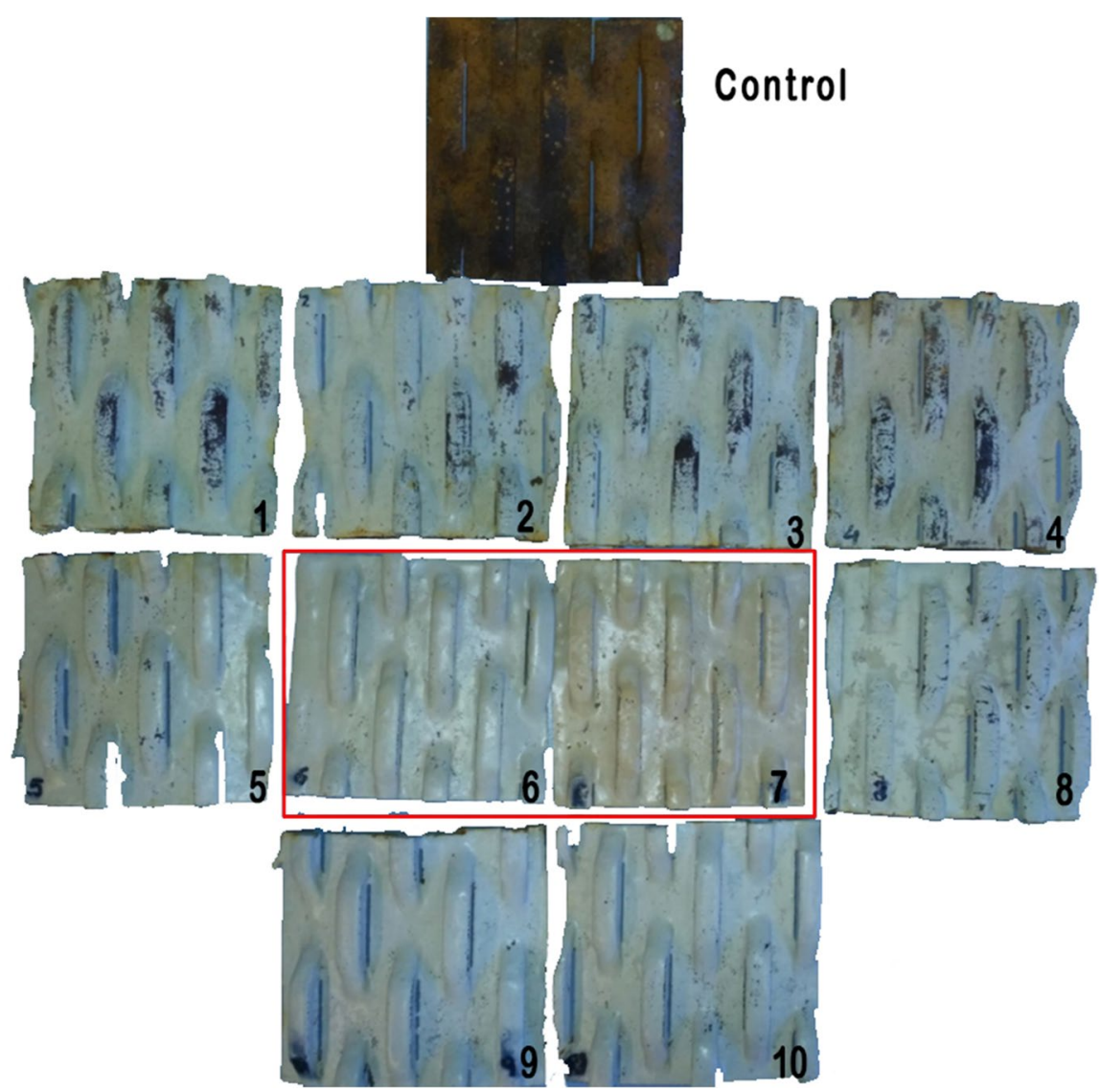


After studies were carried out on a laboratory scale (Fig. 3), metal pipes treated with silver zoolite (treatment) and colloidal silver (treatment 7) were selected for further studies on a pilot-plant scale. In this sense, to establish the level of protection of the coating systems (treatments 6 and 7) in relation to the control, the amount of adhered biomass (biofilm) was determined as well as the number of microorganisms in enriched and minimal culture (Table 5). The experiment on the pilotscale level was developed for a period of 8 weeks, and, together with the previously indicated parameters, other environmental parameters such as $\mathrm{pH}$, dissolved oxygen, and temperature were established (Table 5). The analysis of the environmental characteristics suggests that with small modifications, the metallic sections (with or without coating) were subjected to similar environmental conditions, and, consequently, the different results of microbial colonization can be attributed to the coating of the pipe.

Regarding the amount of adhered biomass in the metallic sections, the data showed a decrease of approximately 50\% (treatment 6) and 20\% (treatment 7) compared to the control (Fig. 4). The weight of the biomass (biofilm) collected from the control plates hovered around $0.2 \mathrm{~g}$ per metal section, while the weights of biomass from treatments 6 and 7 were around $0.1 \mathrm{~g}$ per metal section and $0.16 \mathrm{~g}$ per metal section, respectively.

The results obtained on the pilot-plant scale confirmed those previously observed on the lab scale, suggesting that treatments 6 and 7 (especially 6) protect pipes from biofilm formation under the experimental conditions. As can be observed, the biomass adhered in plates treated with silver zeolite $\left(200 \mathrm{mg} \mathrm{L}^{-1}\right)$ and colloidal silver (treatments 6 and 7) varied significantly during the experimental period. Thus, it could be suggested that inorganic silver materials, especially silver zeolite, behave as strong inhibitors of the formation of microbial biofilms. Although several researchers (Hashimoto, 2001; Klueh et al., 2000; Percival et al., 2012; Saengmee et al., 2013; Song et al., 2011) have reported that silver inhibits biofilm formation, our study shows that not all coatings containing silver have the same inhibition capacity, and it is evident that the coating with silver zeolite provides the best results. Obviously, there is no deep knowledge of the bactericidal mechanisms of the action of silver against microbial cells, although Lara et al. (2010) and $\mathrm{Li}$ et al. (2010) suggested that silver ions can join with structures that envelope microorganisms, such as cell walls or cell membranes, respectively. Probably, the silver zeolite coating in the pipes probably allowed for greater antimicrobial availability and, consequently, a greater inhibitory effect. However, this consideration requires a more detailed study and could be the subject of future analysis.

Together with the study carried out on the formation of biofilms in the metallic sections, we were able to verify that the treatments of the pipes resulted in a lower degree of deterioration. Thus, as can be seen in Fig. 5, the sections covered with silver zeolite did not suffer any visual alteration during the experiment. However, a completely different case was observed in the uncoated pipe, where significant deterioration was evident. Ultimately, the coating with silver zeolite reduces detectable deterioration processes, and, consequently, the pipes are well-protected from the formation of microbial biofilms and other biodeterioration processes.

\section{Conclusions}

Our study shows that the coating of metal pipes with paint containing silver zeolite at a concentration of $2000 \mathrm{mg} \mathrm{L}^{-1}$ drastically inhibits the formation of microbial biofilms and prevents environmental biodeterioration processes. In this sense, silver zeolite showed greater protection capacity than other silver preparations, which suggests that the antimicrobial activity of silver is favoured as silver zeolite. The results seem to suggest that this type of coating presents advantages in relation to others tested, allowing us to suggest that from a practical point of view, the coating with paint containing silver zeolite is more suitable for the protection of metal pipes than other coatings that are currently available. 


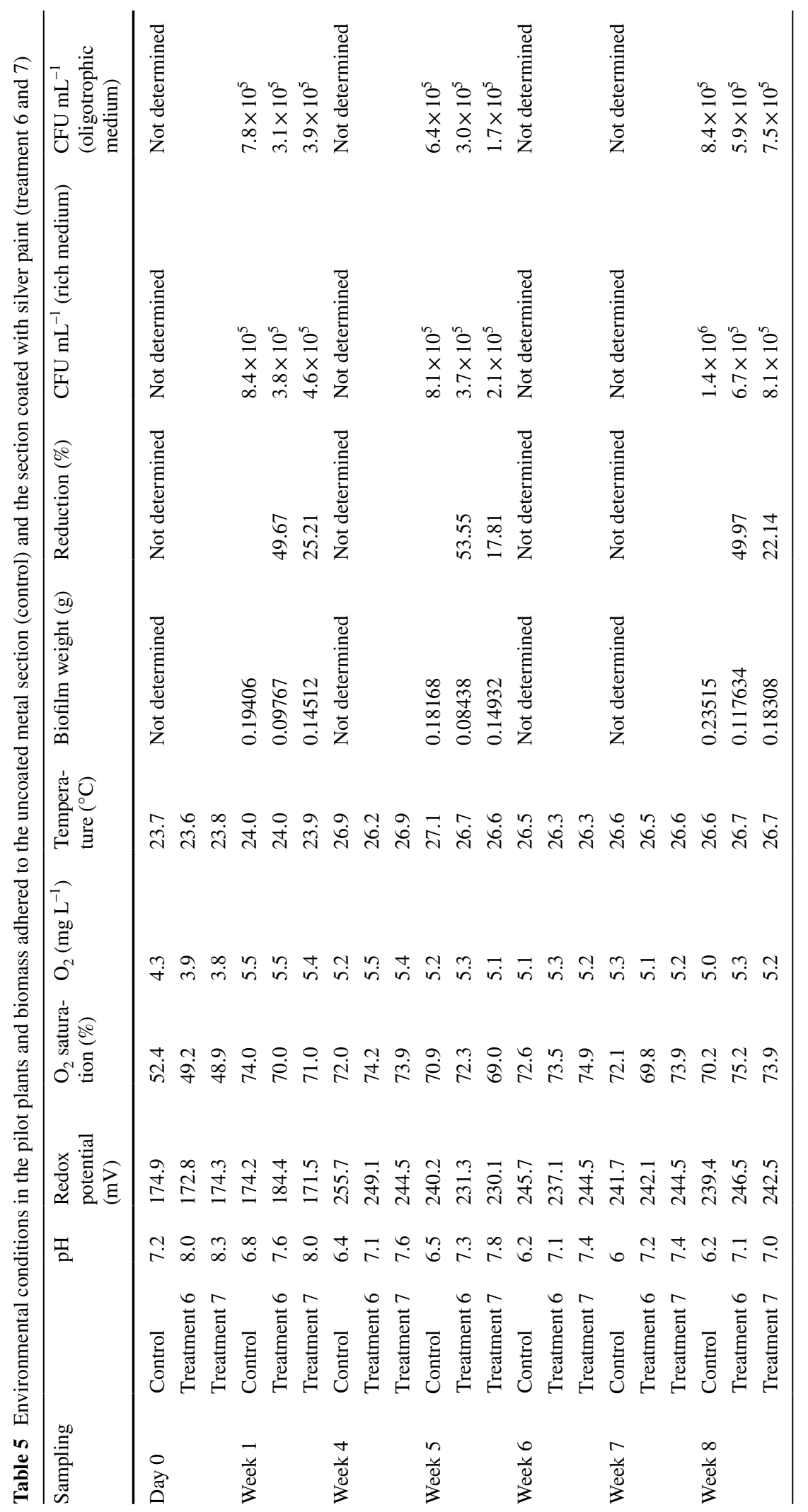


Fig. 4 Biomass adhered to metal sections treated with silver paint (treatments 6 and 7) and sections not treated with silver paint (control). Different letters indicate significant differences among samples

Fig. 5 Images of the metal sections with (treatments 6 and 7) or without (control) a silver coating. Sampling 1, 1 week; sampling 2, 5 weeks; sampling 3 , 8 weeks
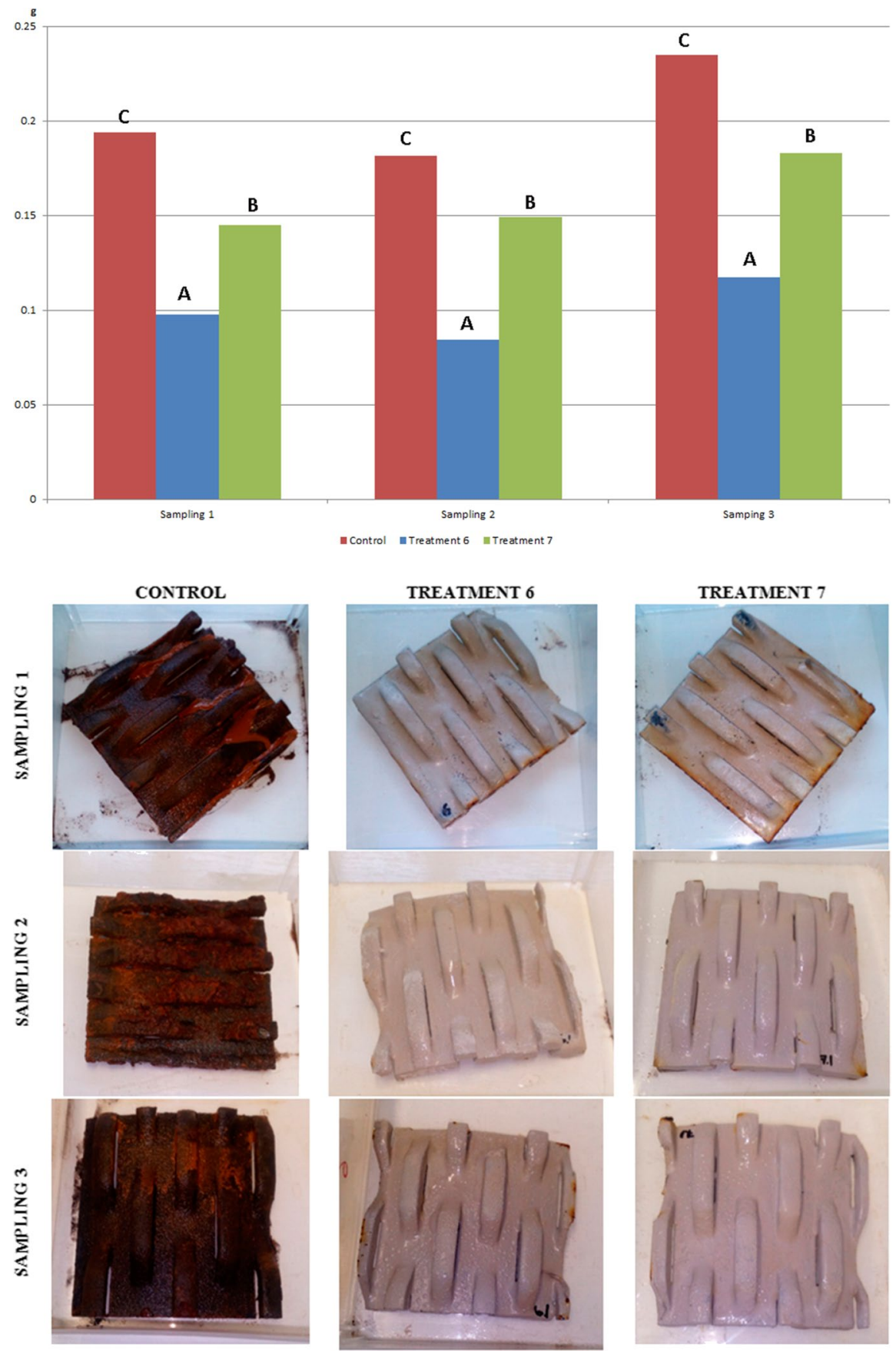

Acknowledgements The authors of this study would like to acknowledge the financial and technical support of the CETAQUA Foundation; without the said support, this work would not have been possible.

Funding Open Access funding provided thanks to the CRUE-CSIC agreement with Springer Nature.
Data Availability The datasets generated during the current study are available from the corresponding author on reasonable request.

Open Access This article is licensed under a Creative Commons Attribution 4.0 International License, which permits use, sharing, adaptation, distribution and reproduction in any 
medium or format, as long as you give appropriate credit to the original author(s) and the source, provide a link to the Creative Commons licence, and indicate if changes were made. The images or other third party material in this article are included in the article's Creative Commons licence, unless indicated otherwise in a credit line to the material. If material is not included in the article's Creative Commons licence and your intended use is not permitted by statutory regulation or exceeds the permitted use, you will need to obtain permission directly from the copyright holder. To view a copy of this licence, visit http://creativecommons.org/licenses/by/4.0/.

\section{References}

Antoniou, A., \& Frank, J. F. (2005). Removal of Pseudomonas putida and associated extracellular polymeric substances from stainless steel by alkali cleaning. Journal of Food Protection, 68, 277-281.

Bremer, P. J., Fillery, S., \& McQuillan, A. J. (2006). Laboratory scale clean-in-place (CIP) studies on the effectiveness of different caustic and acid wash steps on the removal of dairy biofilms. International Journal of Food Microbiology, 106, 254-262.

Cao, H., \& Liu, X. (2010). Silver nanoparticle-modified films versus biomedical device-associated infections. Wiley Interdisciplinary Reviews Nanomedicine and Nanobiotechnology., 2, 670-684.

Cheng, Y. F. (2013). Stress corrosion cracking of pipelines. John Wiley \& Sons.

Dinh, H., Kuever, J., Mußmann, M., et al. (2004). Iron corrosion by novel anaerobic microorganisms. Nature, 427 , 829-832.

Fatemi, P., \& Frank, J. F. (1999). Inactivation of Listeria monocytogenes and Pseudomonas fluorescens biofilms by peracid sanitizers. Journal of Food Protection., 62, 761-765.

Greene, A. K., Few, B. K., \& Serafini, J. C. (1993). A comparison of ozonation and chlorination for the disinfection of stainless steel surfaces. Journal of Dairy Science, 76, 3617-3620.

Groza, A., Ciobanu, C., Iconaru, C., Popa, S., Chapon, P., Luculescu, C., Ganciu, M., \& Predoi, D. (2016). Structural properties and antifungal activity against Candida albicans biofilm of different composite layers based on $\mathrm{Ag} / \mathrm{Zn}$ doped hydroxyapatite-polydimethylsiloxanes. Polymers, $8(131), 153$.

Hashimoto, H. (2001). Evaluation of the anti-biofilm effect of a new antibacterial silver citrate/lecithin coating in an in-vitro experimental system using a modified Robbins device. Journal of the Japanese Association for Infectious Diseases, 75, 678-685.

Husband, P. S., Boxall, J. B., \& Saul, A. J. (2008). Laboratory studies investigating the processes leading to discolouration in water distribution networks. Water Research, 42, 4309-4318.

Jankauskaite, V., Abzalbekuly, B., Lisauskaite, A., Procycevas, I., Fataraite, E., Vitkauskiene, A., \& Janakhmetov, U. (2014). Silicone rubber and microcrystalline cellulose composites with antimicrobial properties. Materials Science, 20, 42-49.

Kim, S. H., Lee, H. S., Ryu, D. S., Choi, S. J., \& Lee, D. S. (2011). Antibacterial activity of silver-nanoparticles against Staphylococcus aureus and Escherichia coli. Korean Journal of Microbiology and Biotechnology, 39, 77-85.

Klueh, U., Wagner, V., Kelly, S., Johnson, A., \&Bryers, J. D. (2000). Efficacy of silver-coated fabric to prevent bacterial colonization and subsequent device-based biofilm formation. Journal of Biomedical Materials Research, 621-631.

Lara, H. H., Ayala-Nunez, N. V., Ixtepan-Turrent, L., \& Rodriguez-Padilla, C. (2010). Bactericidal effect of silver nanoparticles against multidrug-resistant bacteria. World Journal of Microbiology and Biotechnology., 26, 615-621.

Li, W. R., Xie, X. B., Shi, Q. S., Zeng, H. Y., Ou-Yang, Y. S., \& Chen, Y. B. (2010). Antibacterial activity and mechanism of silver nanoparticles on Escherichia coli. Applied Microbiology Biotechnology., 85, 115-122.

Liang, R., Grizzle, R. S., Duncan, K. E., McInerney, M. J., \& Suflita, J. M. (2014). Roles of thermophilic thiosulfatereducing bacteria and methanogenic archaea in the biocorrosion of oil pipelines. Frontiers in Microbioloty, 5, 89.

Lindsay, D., Brözel, V. S., Mostert, J. F., \& Von Holy, A. (2002). Differential efficacy of a chlorine dioxide-containing sanitizer against single and binary biofilms of a dairy associated Bacillus cereus and a Pseudomonas fluorescens isolate. Journal of Applied Microbiology, 92, 352-361.

Lomander, A., Schreuders, P., Russek-Cohen, E., \& Ali, L. (2004). Evaluation of chlorines impact on biofilms on scratched stainless steel surfaces. Bioresources Technology, 94, 275-283.

Marques, S. C., Rezende, J. G. O. S., Alves, L. A. F., Silva, B. C., Alves, E., \& Abreu, L. R. (2007). Formation of biofilms by Staphylococcus aureus on stainless steel and glass surfaces and its resistance to some selected chemical sanitizers. Brazilian Journal of Microbiology, 38, 538-543.

Maruthamuthu, S., Kumar, B., Ramachandran, S., Anandkumar, B., Palanichamy, S., Chandrasekaran, M., Subramanian, P., \& Palaniswamy, N. (2011). Microbial corrosion in petroleum product transporting pipelines. Industrial \& Engineering Chemistry Research, 50, 8006-8015.

Matsumura, Y., Yoshikata, K., Kunisaki, S., \& Tsuchido, T. (2003). Mode of bactericidal action of silver zeolite and its comparison with that of silver nitrate. Applied and Environmental Microbiology, 69(7), 4278-4281.

McNeill, L. S., \& Edwards, M. (2001). Iron pipe corrosion in drinking water distribution systems. $J A W W A$., 93, 88-100.

Midelet, G., \& Carpentier, B. (2004). Impact of cleaning and disinfection agents on biofilm structure and on microbial transfer to a solid model food. Journal of Applied Microbiology, 97, 262-270.

Momba, M. N. B., \& Kfir, R. (Rivka) (2000). An overview of biofilm formation in distribution systems and its impact on the deterioration of water quality. Water Innovations Report, 26(1), 59-66.

Ntsama-Essomba, C., Boutier, S., Ramaldes, M., Dubois-Brissonet, F., \& Fourniat, J. (1997). Resistance of growing 
as biofilms to disinfectants. Veterinary Research, 28, 353-363.

Okoro, C., Olusegun, S., \& Lin, J. (2016). The effects of Tetrakis-hydroxymethylphosphonium sulfate (THPS), nitrite and sodium chloride on methanogenesis and corrosion rates by methanogen populations of corroded pipelines. Corrosion Science, 112, 507-516.

Pan, Y., Breidt, F., Jr., \& Kathariou, S. (2006). Resistance of Listeria monocytogenes biofilms to sanitizing agents in a simulated food processing environment. Applied and Environmental Microbiology, 72, 7711-7717.

Park, A.-I., Daeschel, M. A., \& Zhao, Y. (2004). Functional properties of antimicrobial lysozyme-chitosan composite films. Journal of Food Safety, 69, 215-221.

Percival, S. L., Thomas, J., Linton, S., Okel, T., Corum, L., \& Slone, W. (2012). The antimicrobial efficacy of silver on antibiotic-resistant bacteria isolated from burn wounds. International Wound Journal., 9(5), 488-493.

Pereira, A., Mendes, J., \& Melo, L. F. (2008). Using nanovibrations to monitor biofouling. Biotechnology and Bioengineering., 15, 1407-1415.

Ridgway, H. F., \& Olson, B. H. (1982). Chlorine resistance patterns of bacteria from two drinking water distribution systems. Applied Environmental Microbiology, 44, 972-987.

Rogers, J., Dowsett, A. B., Dennis, P. J., Lee, J. V., \& Keevil, C. W. (1994). Influence of plumbing materials on biofilm formation and growth of Legionella pneumophila in potable water systems. Applied and Environmental Microbiology., 60, 1842-1851.

Saengmee, S., Srikhirin, T., Thaweboon, B., Thaweboon, S., Amornsakchai, T., Dechkunakorn, S., \& Suddhasthira, T. (2013). Antimicrobial effects of silver zeolite, silver zirconium phosphate silicate and silver zirconium phosphate against oral microorganisms. Asian Pacific Journal of Tropical Biomedicine, 3(1), 47-52.

Sánchez-Silva, M., \& Rosowsky, P. E. (2008). Biodeterioration of construction materials: State of the art and future challenges. Journal of Materials in Civil Engineering, 20(5), 352-365.

Santillan, E. F., Choi, W., Bennett, P., \& Leyris, J. D. (2015). The effects of biocide use on the microbiology and geochemistry of produced watering the Eagle Ford formation, Texas, U.S.A. Journal of Petroleum Science and Engineering, 135, 1-9.
Silver, S. (2003). Bacterial silver resistance: Molecular biology and uses and misuses of silver compounds. FEMS Microbiology Reviews, 27, 341-353.

Simoes, M., Pereira, M. O., \& Vieira, M. J. (2005). Effect of mechanical stress on biofilms challenged by different chemicals. Water Research, 39, 5142-5152.

Somers, E. B., \& Wong, A. C. (2004). Efficacy of two cleaning and sanitizing combinations on Listeria monocytogenes biofilms formed at low temperature on a variety of materials in the presence of ready-to-eat-meat residue. Journal of Food Protection., 67, 2218-2229.

Song, J., Kang, H., Lee, C., Hwang, S. H., \& Jang, J. (2011). Aqueous synthesis of silver nanoparticle embedded cationic polymer nanofibers and their antibacterial activity. ACS Applied Material \& Interfaces, 4(1), 460-465.

Szewzyk, U., Szewzyk, R., Manz, W., \& Schleifer, K. H. (2000). Microbiological safety of drinking water. Annual Review of Microbiology., 54, 81-127.

Valix, M., Zamri, D., Mineyama, H., Cheung, W., Shi, J., \& Bustamante, H. (2012). Microbiologically induced corrosion of concrete and protective coatings in gravity sewers. Chinese Journal of Chemical Engineering, 20(3), 433-438.

Videla, H. A., \& Herrera, L. K. (2009). Understanding microbial inhibition of corrosion. A comprehensive overview. International Biodeterioration \& Biodegradation, 63(7), 896-900.

Wai-Yin Sun, R., Chen, R., Chung, N. P. Y., Ho, C. M., Lin, C. L. S., \& Che, C. M. (2005). Silver nanoparticles fabricated in Hepes buffer exhibit cytoprotective activities toward HIV-1 infected cells. Chemical Communications, 40, 5059-5061.

Wallace, W., Rice, J., \& White, D. (1994). Distribution of alginate genes in bacterial isolates from corroded metal surfaces. Microbial Ecology, 27, 213-223.

Weng, Y.-M., Chen, M.-J., \& Chen, W. (1999). Antimicrobial food packing materials from poly (ethylene-co-methacrylic acid). LWT - Food Science and Technology, 32, 191-195.

Publisher's Note Springer Nature remains neutral with regard to jurisdictional claims in published maps and institutional affiliations. 